\title{
Effects of a mix of Bacillus sp. as a potential probiotic for Florida pompano, common snook and red drum larvae performances and digestive enzyme activities
}

\author{
Hauville M. R. ${ }^{1,2,{ }^{*}}$, Zambonino Jose-Luis ${ }^{3}$, Gordon Bell J. ${ }^{1}$, Migaud Herve ${ }^{1}$, Main Kevan L. ${ }^{2}$ \\ ${ }^{1}$ Institute of Aquaculture; University of Stirling; Stirling, UK \\ ${ }^{2}$ Mote Marine Laboratory; Center for Marine and Freshwater Aquaculture Research; Sarasota Florida, \\ ${ }^{3}$ Ifremer; Functional Physiology of Marine Organisms Unit; UMR 6539; Plouzané, France \\ *Corresponding author : M. R. Hauville, email address : $\underline{\text { mrhauville@gmail.com }}$
} USA

\begin{abstract}
:
This study examined the effect of a commercial mix of Bacillus sp. on survival, growth and digestive enzyme activities of Florida pompano, red drum and common snook. Larvae were fed either live feed enriched with Algamac 3050 (Control), Algamac 3050 and probiotics (PB), or the previous diet combined with a daily addition of probiotics to the tank water $(\mathrm{PB}+)$. Survival was not affected by the treatments for any of the species. At the end of the pompano and snook trial, standard lengths of larvae from the $\mathrm{PB}$ and $\mathrm{PB}+$ treatments were significantly greater than for the control larvae. Microbiological analyses were performed at the end of the pompano trial, and numbers of presumptive Vibrio were not a concern in the system. For both pompano and snook, trypsin-specific activity was higher in PB and PB+ larvae compared with the control larvae. Similarly, alkaline phosphatase activity was higher for the pompano larvae fed the PB and PB+ treatments and for the snook larvae fed the PB+ treatment compared with the control larvae. This experiment suggests that a mix of Bacillus sp. can promote growth through an early maturation of the digestive system during the early larval stages of pompano and snook.
\end{abstract}

Keywords : Centropomus undecimalis, digestive enzyme, fish larvae, probiotic, Sciaenops ocellatus, Trachinotus carolinus 


\section{INTRODUCTION}

Marine fish larvae undergo major physiological and morphological changes during the first weeks of their lives (Péres et al. 1997). Inadequate nutrition and larval rearing conditions during this crucial transitional period adversely affect the development and the future success of the larvae (Yúfera and Darias 2007). Determining optimal rearing protocols has proven difficult in marine fish due to the small size and fragility of the larvae, therefore, the mass production of robust juveniles remains a challenge for most species (Hamre et al. 2013). The external environment has a major impact on marine fish gastrointestinal microflora as osmoregulation requires constant ingestion of the surrounding water (Gatesoupe 1999). Since the digestive tract of fish larvae is sterile at hatching, the initial colonization depends on the environment and live feed ingested (Grisez et al. 1997). The initial microflora established at the larval stage seems to persist after metamorphosis, it is therefore thought that providing probiotics as soon as possible after hatching can have beneficial effects (Ringø and Vadstein 1998). In addition, the larvae immune system is immature and relies on nonspecific defense mechanisms, thus a healthy microflora constitutes a crucial primary barrier to which probiotics can, most likely, effectively contribute (Hansen and Olafsen 1999).

Probiotics are 'live microorganisms which when administered in adequate amounts confer a health benefit to the host' (Aureli et al. 2011). In humans, Hooper et al. (2001) demonstrated that probiotics can modulate the expression of genes involved in nutrient absorption, mucosal barrier fortification and postnatal intestinal maturation. Bacteria communicate via the use of quorum-sensing molecules, which regulate gene expression mainly when the population has reached a high cell density (Williams et al. 2007). B. subtilis was found to produce a quorumsensing pentapeptide, the competence and sporulation-stimulating factor (CSF), which activates two cellular survival pathways (protein kinase B and p38 mitogen-activated protein kinase) and induces the expression of the heat shock protein (e.g. Hsp27) in intestinal 
epithelial cells (Fujiya et al. 2007). Hsp protect cells against various stresses and this mechanism is highly conserved throughout evolution and across species (Parsell and Lindquist 1993). When over expressed, Hsp increase intestinal epithelial cells viability and protect from oxidative injury, contributing to intestinal homeostasis (Tao et al. 2006).

Probiotics have various modes of actions including the competitive exclusion of pathogenic bacteria (Moriarty 1997, Gomez-Gil et al. 2000, Chythanya et al. 2002, Balcázar et al. 2004, Vine et al. 2004), the improvement of water quality (Moriarty 1997), the enhancement of the immune system (Gatesoupe 1999, Balcázar et al. 2004, Picchietti et al. 2009, Zhou et al. 2010) and the stimulation of the digestive system (Suzer et al. 2008, Lazado et al. 2012).

Among the probiotics, Bacillus is of particular interest as it is a spore forming bacteria (Cutting 2011). Spore production is triggered by nutrient depletion in the bacterial environment, allowing for long-term survival in conditions inadequate to vegetative bacteria. Even though spores are dehydrated and have an inactive metabolism, they are able to monitor the environment (Nicholson et al. 2000). Under appropriate conditions, germination occurs by allowing water to penetrate the spore and vegetative growth resumes (Moir 2006). The spore surface layer confers outstanding resistance to extreme physical and chemical stress (Henriques and Moran 2007). Spores are heat stable and can survive the low $\mathrm{pH}$ of the gastric barrier (Spinosa et al. 2000). Therefore, they can be stored at room temperature in a desiccated form for a long period of time and all of the administrated spores will reach the intestinal tract (Cutting 2011). In addition, production cost is low, making Bacillus particularly valuable for use in aquaculture production (Wang et al. 2008).

In fish, the administration of Bacillus was found to positively influence expression of genes involved in growth metabolism and animal welfare in sea bream (Avella et al. 2010). In the same species, Bacillus was shown to increase the expression of occludin, a trans-membrane component of tight junctions in the intestine, suggesting an improvement of cell junction 
integrity between enterocytes (Cerezuela et al. 2013). On white shrimp Penaeus vannamei, a Bacillus coagulants supplementation improved growth performances and enhanced the immune response through antibacterial activity as well as an increase in phenoloxidase, superoxide dismutase and peroxidase activities (Wang and $\mathrm{Gu} 2010$ ). In addition, studies have demonstrated, but not explained, the ability for Bacillus to increase resistance to vibrio in black tiger shrimp Penaeus monodon (Vaseeharan and Ramasamy 2003), common snook, Centropomus undecimalis (Kennedy et al. 1998) and sea bass Dicentrarchus labrax (Touraki et al. 2012); increase growth and stimulate the digestive system in Indian white shrimp Fenneropenaeus indicus (Ziaei-Nejad et al. 2006), Pacific white shrimp Penaeus vannamei (Wang 2007), Japanese flounder Paralichthys olivaceus (Ye et al. 2011), orange-spotted grouper Epinephelus coioides (Sun et al. 2013), rohu Labeo rohita (Mohapatra et al. 2012) and common carp Cyprinus carpio (Wang and Zirong 2006); promote growth and improve tolerance to rearing conditions in sea bream Sparus aurata (Avella et al. 2010).

The present study aimed to test the effects of a commercial mix of Bacillus (Sanolife MIC-F, INVE Technologies, Belgium) on the growth and digestive enzyme activities in early larval stages of some of Florida's high-value marine food fish (Florida pompano Trachinotus carolinus and red drum Sciaenops ocellatus) and stock enhancement species (common snook Centropomus undecimalis). 


\section{MATERIALS AND METHODS}

\section{Experimental animals}

Snook and pompano eggs were obtained from broodstock captured on the southwest Florida coast and held at the Mote Marine Laboratory Aquaculture Research Park in Sarasota, Florida. Broodstock were conditioned through photothermal regimes in tanks $\left(25 \mathrm{~m}^{3}\right.$ for pompano, $45 \mathrm{~m}^{3}$ for snook) equipped with recirculating filtration systems. Spawning was induced by implanting mature pompano females with $50 \mu \mathrm{g} \cdot \mathrm{kg}^{-1}$ of sGnRHa $\left(\mathrm{Ovaplant}^{\circledR}\right)$ and mature snook females with $50 \mu \mathrm{g} \cdot \mathrm{kg}^{-1}$ of sGnRHa from the Institute of Marine and Environmental Technology of the University of Maryland. Red drum eggs were received from captive broodstock held at the Florida Fish and Wildlife Conservation Commission Stock Enhancement Research Facility.

Eggs for each species were incubated in a $100 \mathrm{~L}$ hatching tank with aeration and an upwelling water circulation from a $3 \mathrm{~m}^{3}$ system with UV and bio-filtration. Fertilization and hatching rates were respectively $54.5 \%$ and $73.2 \%$ for pompano and $83.5 \%$ and $85.2 \%$ for snook. The fertilization rate of the red drum eggs was unknown while the hatching rate reached $90.2 \%$.

\section{Experimental set up and treatments}

The experimental set up included three identical independent systems. Each system was composed of four $100 \mathrm{~L}$ tanks with water recirculating from the tanks to a biofilter and back to the tanks via a UV light. Each independent system was assigned a treatment to avoid probiotic cross contamination.

After hatching, larvae were volumetrically counted and transferred to the experimental tanks at 100 larvae per liter for pompano and red drum, and 200 larvae per liter for snook according to standard procedures at the research park. For all species, photoperiod was maintained at 
12h dark: $12 \mathrm{~h}$ light, salinity at $35 \pm 1 \mathrm{~g} . \mathrm{L}^{-1}$, temperature at $27 \pm 1^{\circ} \mathrm{C}$, pH at $8 \pm 0.5$, dissolved oxygen at $6 \pm 2 \mathrm{mg} \cdot \mathrm{L}^{-1}$. From 2 days post hatch (DPH), rotifers were fed twice a day at 5 rotifers per $\mathrm{mL}$. In addition, a microdiet (Gemma, Skretting, France) was delivered twice a day in between rotifer feeding.

Trials were stopped at the end of the rotifer-feeding period for pompano (9 DPH) and snook (12 DPH). The red drum trial was extended up to $21 \mathrm{DPH}$ due to the lack of significant difference in growth at the end of the rotifer-feeding period (10 DPH). In this case, rotifer density was decreased to 3 per $\mathrm{ml}$ at $7 \mathrm{DPH}$ and the fish weaned onto the microdiet from 10 $\mathrm{DPH}$.

Three treatments were tested in quadruplicate for all trials. The first treatment (control) was rotifers enriched with Algamac 3050 (Aquafauna Bio-Marine Inc, USA). The second treatment (PB) was rotifers enriched with Algamac 3050 and a commercial mix of Bacillus spp. (0.5 g per liter of enrichment according to manufacturer's recommendations, concentration of bacteria: minimum $\left.1 \times 10^{10} \mathrm{CFU} / \mathrm{g}\right)$. The third treatment $(\mathrm{PB}+)$ was the second treatment, with additional probiotics $\left(5 \mathrm{~g} . \mathrm{m}^{-3}\right.$, according to manufacturer's recommendations) added daily directly to the tank water.

\section{Sampling}

Larvae growth was monitored through standard length measurement of 10 larvae from each tank (40 per treatment) at 1, 5 and $9 \mathrm{DPH}$ for pompano; 1, 5, 9, and $12 \mathrm{DPH}$ for snook; 1, 7, 14 and $21 \mathrm{DPH}$ for red drum. Pompano larvae body depth was also recorded in consideration to the particular short, deep and compressed pompano body shape. At the end of the trials, 50 larvae from each tank (200 per treatment) were preserved at $-70^{\circ} \mathrm{C}$ for enzyme analysis. In addition, at the end of the pompano trial, 25 larvae from each tank (100 per treatment) were preserved at $4^{\circ} \mathrm{C}$ for bacterial analyses performed the following day. 


\section{Enzyme and bacterial analyses}

Enzyme analyses were performed at the Functional Physiology of Marine Organisms unit at Ifremer in Brest, France. Larvae from each tank were pooled and homogenized prior to all analyses. Trypsin, amylase, alkaline phosphatase (AP) and leucine-alanine peptidase (Leuala) activities were assayed according to Holm et al. (1988), Métais and Bieth (1968), Bessey et al. (1946) and Nicholson and Kim 1975, respectively. Enzyme activity results are expressed as specific activities, i.e. U.mg ${ }^{-1}$ protein. Protein was determined by the Bradford procedure (Bradford 1976). Due to technical difficulties, red drum larvae sampled at the end of the rotifer feeding period $(7 \mathrm{dph})$ could not be processed and enzyme analyses were performed at $21 \mathrm{dph}$ only, therefore, results from the red drum trial are presented separately in table 2 .

Bacterial analyses were performed at the Mote Marine Laboratory, Center for Marine Microbiology. Larvae from each tank were pooled and rinsed three times with sterile seawater then ground using a PowerSoil ${ }^{\circledR}$ DNA isolation kit (MO-BIO Laboratories, Inc., USA). Serial dilutions of the homogenates were then plated on marine agar (promoting the growth of all marine heterotrophs) and TCBS (medium selective of Vibrio sp.) media. The petri dishes were incubated at $22{ }^{\circ} \mathrm{C}$ and the number of colony-forming units were counted 48 hours after plating.

\section{Probiotic strains identification}

One gram of the commercial mix was diluted in $99 \mathrm{ml}$ of Phosphate-Buffered Saline (PBS) and mixed thoroughly. An inoculating loopful of the suspension was then plated following the quadrant method on Trypticase Soy Agar (TSA) media. The plate was incubated inverted at $37{ }^{\circ} \mathrm{C}$ overnight. Colonies showing distinct morphologies were sub-cultured on TSA media 
following the same method. Isolated strains were sent for $16 \mathrm{~S}$ rDNA sequencing identification to Accugenix, Inc. (Newark, DE, USA).

\section{Statistical analysis}

Statistical analyses were performed using MINITAB $^{\circledR}$ version 16.0. Normality and homogeneity of variance were confirmed using Kolmogorov-Smirnov test. Growth and body depth data were analyzed using a General Linear Model (GLM) with all time and treatment interactions being analyzed and significant differences tested by a Tukey post-hoc test with $95 \%$ confidence. Bacterial counts and enzyme activities were compared by a one-way ANOVA followed by a Tukey post hoc test with $95 \%$ confidence. Survival data was arcsine square root transformed before a one-way ANOVA followed by a Tukey post-hoc test with $95 \%$ confidence.

\section{RESULTS}

\section{Bacillus strains identification}

Three Bacillus strains were isolated from the commercial mix. The $16 \mathrm{~S}$ rDNA sequencebased identified the following species: Bacillus licheniformis, Bacillus amyloliquefaciens plantarum/methylotrophicus and Bacillus pumilus/safensis. In the two later cases, the strain matched two closely related species that cannot be differentiated by $16 \mathrm{~S}$ rDNA (Fig. 1).

\section{Survival}

No significant difference in survival from hatching to the end of the trial was observed between treatments regardless of the species. However, survival was significantly higher in pompano $(7.6 \pm 1.9 \%)$ and red drum $(9.9 \pm 0.8 \%)$ compared to snook $(2.4 \pm 0.7 \%)$ (Fig.2). 
During the snook trial, poor survival led to the termination of one PB tank at $7 \mathrm{DPH}$, as well as one Control and one PB+ tank at DPH 9.

\section{Growth}

At the end of the pompano trial, $\mathrm{PB}$ and $\mathrm{PB}+$ larvae had significantly greater standard length (Fig. 3A) and body depth (Fig. 3B) than the control larvae with $4.34 \pm 0.10,4.22 \pm 0.07$ and $3.89 \pm 0.09 \mathrm{~mm}$, respectively for standard length and $0.88 \pm 0.01,0.83 \pm 0.03$ and $0.66 \pm$ 0.01 , respectively for body depth. The same was true for snook larvae standard length with $3.69 \pm 0.02,3.60 \pm 0.03$ and $3.29 \pm 0.03 \mathrm{~mm}$, respectively for $\mathrm{PB}, \mathrm{PB}+$ and control larvae (Fig. 3C). However, no significant difference was observed for body depth with an average of $0.71 \pm 0.20 \mathrm{~mm}$ at the end of the experiment (Fig. 3D). At the end of the red drum trial, no difference was observed between treatments with an average of $5.44 \pm 0.07 \mathrm{~mm}$ (Table 1).

\section{Bacterial analyses}

Results from the microbiological analyses on the pompano larvae showed significantly higher counts of colony-forming units (CFU) per larvae on the marine agar media for the larvae fed the probiotics supplementation $\left(38.10^{3} \pm 8.10^{3} \mathrm{CFU}\right.$ for $\mathrm{PB}$ and $18.10^{3} \pm 22.10^{3} \mathrm{CFU}$ for $\mathrm{PB}+)$ compared to the control larvae $\left(10^{3} \pm 0.6 \cdot 10^{3} \mathrm{CFU}\right)$. Numbers of presumptive Vibrio on the TCBS media were low and not significantly different between treatments with an average of $0.06 \pm 10^{3} \mathrm{CFU}$ per larvae (Table 2).

\section{Enzyme activities}

For both pompano and snook, trypsin specific activities at the end of the trial were significantly higher in larvae fed the $\mathrm{PB}$ and the $\mathrm{PB}+$ treatments compared to the control larvae. Trypsin activities of snook larvae from the $\mathrm{PB}$ and $\mathrm{PB}+$ treatments were respectively 
$37.3 \%$ and $29.6 \%$ higher than that of control larvae, while trypsin activities of pompano larvae from the same treatments were respectively $45.1 \%$ and $46.8 \%$ higher than that of control larvae (Fig. 4a).

Difference in amylase activity was only observed for snook larvae, with activities of larvae from the PB+ treatment $65.2 \%$ higher than that of control larvae (Fig. $4 \mathrm{~b}$ ).

$\mathrm{AP}$ activities of pompano larvae from the $\mathrm{PB}$ and $\mathrm{PB}+$ treatments and snook larvae from the $\mathrm{PB}+$ treatment were higher than that of control larvae. AP activity of snook larvae from the $\mathrm{PB}+$ treatments was $27.1 \%$ higher than that of control larvae while AP activities of pompano larvae from the $\mathrm{PB}$ and $\mathrm{PB}+$ treatments were respectively $27.9 \%$ and $28.0 \%$ higher than that of control larvae. For all treatments, AP activities of pompano larvae were significantly higher than that of snook larvae (Fig. 4c).

For both snook and pompano, no significant differences were observed in Leu-ala activities between treatments or between species (Fig. 4d).

No significant differences were observed in the activities of the enzymes tested for red drum at the end of the trial (Table 1). 


\section{DISCUSSION}

This series of experiments clearly suggested a beneficial effect of Bacillus probiotic on growth and digestive enzyme activity of Florida pompano and Common snook larvae when supplemented during the early larval stages. Similar results have been observed with Indian white shrimp (Ziaei-Nejad et al. 2006), common carp (Wang and Zirong 2006), Pacific white shrimp (Wang 2007), Japanese flounder (Ye et al. 2011), rohu (Mohapatra et al. 2012) and orange-spotted grouper (Sun et al. 2013).

The three strains identified in the commercial mix are species closely related to Bacillus subtilis however, they differ metabolically and secrete different enzymes (Priest et al. 1987). B. pumilus isolated from the gut of rohu fingerlings was found to produce amylase and cellulase (Ghosh et al. 2002) and it demonstrated strong inhibition against several strains of Vibrio sp. when isolated from the gut of black tiger shrimp (Hill et al. 2009). B. licheniformis has been reported to have antiviral properties through the induction of cytokines (Arena et al. 2006) and to produce an antimicrobial peptide with a broad inhibitory spectrum (CladeraOlivera et al. 2004). In addition it was shown to produce phytase when isolated from several freshwater cultured fish (Dan and Ray 2013). B. amyloliquefaciens is closely related to $B$. subtilis and used to be given a subspecies status (B. subtilis subsp. amyloliquefaciens) before additional studies demonstrated the numerous physiological and biochemical specificities of B. amyloliquefaciens (Priest et al. 1987). One of the main differences between the two species is the ability of $B$. amyloliquefaciens to produce more extracellular enzyme than $B$. subtilis, including between 50 and 150 times more $\alpha$-amylase (Welker and Campbell 1967, Priest et al. 1987). In fish, B. amyloliquefaciens was found to have an inhibitory effect on pathogenic Aeromonas hydrophila associated with the eel Anguilla anguilla (Cao et al. 2011), and improved growth, feed conversion ratio and immunological parameters in Nile 
tilapia Oreochromis niloticus (Ridha and Azad 2012). The addition of either B. subtilis, B. licheniformis or B. pumilus to the diet of olive flounder Paralichthys olivaceus, led to different effects with B. subtilis increasing growth, B. subtilis and B. pumilus increasing survival rate, and B. pumilus and B. licheniformis increasing superoxide dismutase activity and disease resistance (Cha et al. 2013). These results highlight the interest of supplementing several strains of probiotics simultaneously. Nonetheless, it is likely that the inclusion rate of each strain will impact on the final effect of the product and therefore manufacturers should communicate not only on the qualitative characteristics of their product, but also on the quantitative characteristics.

Several modes of action are proposed to explain the positive effect of probiotics, including antagonism towards pathogens, competition for adhesion sites and competitions for nutrients (Ray et al. 2012). However, the microbiological analyses on the pompano larvae at the end of the trial did not show high vibrio counts in any of the treatments. Therefore, it was assumed that in the experimental system used for these trials, pathogenic bacteria were not a major issue and no microbiological analyses were performed for the other species. Counts of heterotrophic bacteria were significantly higher in the $\mathrm{PB}$ and $\mathrm{PB}+$ treatments compared to the control, confirming the presence of the probiotics in the gut of the larvae.

Probiotics can also act on the digestive system of their host. Poorly developed at hatching, the digestive system of marine fish larvae matures progressively, evolving from an intracellular mode of digestion via pinocytosis, to an adult mode of digestion involving membrane transport with the development of the brush border membrane (Govoni et al. 1986). Alkaline phosphatase, an enzyme mainly located in the brush border membrane of enterocytes, is therefore a good indicator of intestinal development (Cahu and Zambonino-Infante 1995). Simultaneously to the intestine maturation, the functional maturation of the pancreas occurs, with an activity increase of proteolytic enzymes, including trypsin, and a decrease in the 
carbolytic enzyme amylase (Cahu and Zambonino-Infante 1994). In this study, results from the enzyme analyses showed an increase in trypsin specific activity for the pompano and snook larvae fed the probiotic supplementation. In addition, the specific activity of alkaline phosphatase was significantly higher for pompano larvae fed the $\mathrm{PB}$ and $\mathrm{PB}+$ treatments and for snook larvae fed the $\mathrm{PB}+$ treatment, suggesting an early maturation of the digestive system. The higher amylase specific activity in snook larvae fed the $\mathrm{PB}+$ treatment might be due to a higher capacity of snook to utilize carbohydrates, which could be stimulated by the important extracellular amylase production by $B$. amyloliquefaciens. Very little is known about the natural diet of the early larval stage of snook and pompano and more research is needed to understand such variations.

It was hypothesized that the increase in enzyme activities observed with the use of probiotics could be due to the exoenzymes produced by the bacteria (Bairagi et al. 2002, Balcázar et al. 2006). Nonetheless, Ziaei-Nejad et al. (2006) demonstrated that the proportion of enzyme synthesized by the probiotics could only contribute to a very small amount of the total enzyme activity of the gut and suggested that instead, the probiotics stimulate the production of endogenous enzymes.

In the present study, the increased level of maturation of the enterocytes of the snook and pompano larvae fed the probiotic supplementation suggested an increased absorptive capacity of the brush-border membrane leading to more efficient feed utilization and better growth.

Pompano and snook larvae are not as robust as red drum larvae and seem to benefit more from the probiotic supplementation. However, no detrimental effect was observed for the red drum larvae and the probiotics might have influenced factors other than growth and digestive enzyme activity, such as disease and stress resistance, intestinal epithelium structure or general welfare as discussed above. In addition, a longer trial period might have revealed some differences in growth as Ridha and Azad (2012) did not observe any growth differences 
after 99 days when juvenile Nile tilapia were fed a diet enriched with Bacillus but observed differences 61 day after the end of the treatment compared to the control treatment. Moreover, a higher level of probiotic supplementation might be necessary. Indeed, Merrifield et al. (2010) showed that high intestinal levels of B. subtilis and B. licheniformis ( $>80 \%)$ are required to improve rainbow trout growth performance and feed utilization.

No difference in survival was observed between treatments for all species although an increase in survival would be expected alongside the advanced digestive system maturation and improved growth, especially for snook where survival is very low. Many factors participate in the survival of young fish larvae and snook being a relatively new species in aquaculture, many rearing aspects still need to be explored and improved. Even though the probiotic supplementation did not increase survival it is likely that larvae with improved growth and digestive capabilities will be more robust and a difference in survival might be observed after critical life events such as metamorphosis and weaning.

In conclusion, these experiments demonstrated positive effects from the mix of Bacillus on the development of pompano and snook larvae through an early maturation of the digestive tract. To obtain optimal effects, a supplementation through both the live feed and the tank water seems recommended. Further research is needed to better understand the mode of action of probiotics and the mechanisms involved during the ontogeny of the digestive system.

\section{ACKNOWLEDGEMENTS}

Funding for this study was provided by the University of Stirling, the Florida Department of Agriculture and Consumer Services, Adam H. Putnam, Commissioner, Contract No. 017138, Florida Fish and Wildlife Conservation Commission (Contract No.10087, Permit \# SAL 09- 
522-SR), and the National Sea Grant College Program of the U.S. Department of Commerce's National Oceanic and Atmospheric Administration (NOAA), Grant No. NA10OAR4170079. The views are those of the authors and do not necessarily reflect the view of these organizations. The authors would like to thank the research team at the Mote Marine Laboratory Aquaculture Park, as well as Dr Kimberly Ritchie from the Mote Marine Laboratory Microbiology Program for her assistance with the microbiological analysis and data interpretation, and Christine Huelvan from the Functional Physiology of Marine Organisms Unit at IFREMER for her assistance with the enzyme analyses. 


\section{REFERENCES}

Arena, A., Maugeri, T.L., Pavone, B., Iannello, D., Gugliandolo, C., and Bisignano, G., 2006. Antiviral and immunoregulatory effect of a novel exopolysaccharide from a marine thermotolerant Bacillus licheniformis. International immunopharmacology, 6 (1), 8-13.

Aureli, P., Capurso, L., Castellazzi, A.M., Clerici, M., Giovannini, M., Morelli, L., Poli, A., Pregliasco, F., Salvini, F., and Zuccotti, G.V., 2011. Probiotics and health: an evidencebased review. Pharmacological research: the official journal of the Italian Pharmacological Society, 63 (5), 366-76.

Avella, M.A., Gioacchini, G., Decamp, O., Makridis, P., Bracciatelli, C., and Carnevali, O., 2010. Application of multi-species of Bacillus in sea bream larviculture. Aquaculture, 305 (1-4), 12-19.

Bairagi, A., Ghosh, K.S., Kumar, S., and Ray, A.K., 2002. Enzyme producing bacterial flora isolated from fish. Aquaculture International, 10 (1), 109-121.

Balcázar, J.L., de Blas, I., Ruiz-Zarzuela, I., Cunningham, D., Vendrell, D., and Múzquiz, J.L., 2006. The role of probiotics in aquaculture. Veterinary microbiology, 114 (3-4), $173-86$.

Balcázar, J.L., Vendrell, D., de Blas, I., Ruiz-Zarzuela, I., and Muzquiz, J.L., 2004. Probiotics: a tool for the future of fish and shellfish health management. Journal of Aquaculture in the Tropics, 19 (4), 239-242.

Bessey, O.A., Lowry, O.H., and Brock, M.J., 1946. A method for the rapid determination of alkaline phosphates with five cubic millimeters of serum. The Journal of Biological Chemistry, 164, 321-9.

Bradford, M.M., 1976. A rapid and sensitive method for the quantitation of microgram quantities of protein utilizing the principle of protein-dye binding. Analytical Biochemistry, 72, 248-54.

Cahu, C.L. and Zambonino-Infante, J.L., 1994. Early weaning of sea bass (Dicentrarchus labrax) larvae with a compound diet: Effect on digestive enzymes. Comparative Biochemistry and Physiology Part A: Physiology, 109 (2), 213-222.

Cahu, C.L. and Zambonino-Infante, J.L., 1995. Maturation of the pancreatic and intestinal digestive functions in sea bass (Dicentrarchus labrax): effect of weaning with different protein sources. Fish Physiology and Biochemistry, 14 (6), 431-437.

Cao, H., He, S., Wei, R., Diong, M., and Lu, L., 2011. Bacillus amyloliquefaciens G1: A Potential Antagonistic Bacterium against Eel-Pathogenic Aeromonas hydrophila. Evidence-based complementary and alternative medicine : eCAM, 2011, 824104. 
Cerezuela, R., Meseguer, J., and Esteban, M.Á., 2013. Effects of dietary inulin, Bacillus subtilis and microalgae on intestinal gene expression in gilthead seabream (Sparus aurata L.). Fish \& shellfish immunology, 34 (3), 843-8.

Cha, J.-H., Rahimnejad, S., Yang, S.-Y., Kim, K.-W., and Lee, K.-J., 2013. Evaluations of Bacillus spp. as dietary additives on growth performance, innate immunity and disease resistance of olive flounder (Paralichthys olivaceus) against Streptococcus iniae and as water additives. Aquaculture, 402-403, 50-57.

Chythanya, R., Karunasagar, I., and Karunasagar, I., 2002. Inhibition of shrimp pathogenic vibrios by a marine Pseudomonas I-2 strain. Aquaculture, 208 (1-2), 1-10.

Cladera-Olivera, F., Caron, G.R., and Brandelli, a., 2004. Bacteriocin-like substance production by Bacillus licheniformis strain P40. Letters in Applied Microbiology, 38 (4), $251-256$.

Cutting, S.M., 2011. Bacillus probiotics. Food microbiology, 28 (2), 214-20.

Dan, S.K. and Ray, A.K., 2013. Characterization and identification of phytase-producing bacteria isolated from the gastrointestinal tract of four freshwater teleosts. Annals of Microbiology.

Fujiya, M., Musch, M.W., Nakagawa, Y., Hu, S., Alverdy, J., Kohgo, Y., Schneewind, O., Jabri, B., and Chang, E.B., 2007. The Bacillus subtilis quorum-sensing molecule CSF contributes to intestinal homeostasis via OCTN2, a host cell membrane transporter. Cell host \& microbe, 1 (4), 299-308.

Gatesoupe, F.-J., 1999. The use of probiotics in aquaculture. Aquaculture, 180 (1-2), 147165.

Ghosh, K., Sen, K.S., and Ray, A.K., 2002. Characterization of Bacilli Isolated from the Gut of Rohu , Labeo rohita , Fingerlings and Its Significance in Digestion. Journal of Applied Aquaculture, 12 (3), 33-42.

Gomez-Gil, B., Roque, A., and Turnbull, J.F., 2000. The use and selection of probiotic bacteria for use in the culture of larval aquatic organisms. Aquaculture, 191 (1-3), 259270.

Govoni, J.J., Boehlert, G.W., and Watanabej, Y., 1986. The physiology of digestion in fish larvae. Environmental Biology of Fishes, 16 (1-3), 59-77.

Grisez, L., Reyniers, J., Verdonck, L., Swings, J., and Ollevier, F., 1997. Dominant intestinal microflora of sea bream and sea bass larvae, from two hatcheries, during larval development. Aquaculture, 155 (1-4), 387-399.

Hamre, K., Yúfera, M., Rønnestad, I., Boglione, C., Conceição, L.E.C., and Izquierdo, M., 2013. Fish larval nutrition and feed formulation: knowledge gaps and bottlenecks for advances in larval rearing. Reviews in Aquaculture, 5, S26-S58. 
Hansen, G.H. and Olafsen, J.A., 1999. Bacterial Interactions in Early Life Stages of Marine Cold Water Fish. Microbial Ecology, 38 (1), 1-26.

Henriques, A.O. and Moran, C.P., 2007. Structure, assembly, and function of the spore surface layers. Annual review of microbiology, 61, 555-88.

Hill, J.E., Baiano, J.C.F., and Barnes, a C., 2009. Isolation of a novel strain of Bacillus pumilus from penaeid shrimp that is inhibitory against marine pathogens. Journal of fish diseases, 32 (12), 1007-16.

Holm, H., Hanssen, L.E., Krogdahl, A., and Florholmen, J., 1988. High and low inhibitor soybean meals affect human duodenal proteinase activity differently: in vivo comparison with bovine serum albumin. The Journal of Nutrition, 118 (4), 515-520.

Hooper, L. V, Wong, M.H., Thelin, a, Hansson, L., Falk, P.G., and Gordon, J.I., 2001. Molecular analysis of commensal host-microbial relationships in the intestine. Science (New York, N.Y.), 291 (5505), 881-4.

Kennedy, S.B., Tucker, J.W., Neidig, C.L., Vermeer, G.K., Cooper, V.R., Jarrell, J.L., and Sennett, D.G., 1998. Bacterial Management Strategies For Stock Enhancement Of Warmwater Marine Fish: A Case Study With Common Snook (Centropomus Undecimalis ). Bulletin of Marine Science, 62 (2), 573-588.

Lazado, C.C., Caipang, C.M.A., and Kiron, V., 2012. Enzymes from the gut bacteria of Atlantic cod, Gadus morhua and their influence on intestinal enzyme activity. Aquaculture Nutrition, 18 (4), 423-431.

Merrifield, D.L., Bradley, G., Baker, R.T.M., and Davies, S.J., 2010. Probiotic applications for rainbow trout (Oncorhynchus mykiss Walbaum) II. Effects on growth performance, feed utilization, intestinal microbiota and related health criteria postantibiotic treatment. Aquaculture Nutrition, 16 (5), 496-503.

Métais, P. and Bieth, J., 1968. Determination of alpha-amylase by a microtechnic. Annales de biologie clinique, 26 (1), 133-42.

Mohapatra, S., Chakraborty, T., Prusty, a. K., Das, P., Paniprasad, K., and Mohanta, K.N., 2012. Use of different microbial probiotics in the diet of rohu, Labeo rohita fingerlings: effects on growth, nutrient digestibility and retention, digestive enzyme activities and intestinal microflora. Aquaculture Nutrition, 18 (1), 1-11.

Moir, A., 2006. How do spores germinate? Journal of applied microbiology, 101 (3), 526-30.

Moriarty, D.J.W., 1997. The role of microorganisms in aquaculture ponds. Aquaculture, 151 (1-4), 333-349.

Nicholson, J.A. and Kim, Y.S., 1975. A one-step 1-amino acid oxidase assay for intestinal peptide hydrolase activity. Analytical Biochemistry, 63 (1), 110-117. 
Nicholson, W.L., Munakata, N., Horneck, G., Melosh, H.J., and Setlow, P., 2000. Resistance of Bacillus Endospores to Extreme Terrestrial and Extraterrestrial Environments. Microbiology and Molecular Biology Reviews, 64 (3), 548-572.

Parsell, D.A. and Lindquist, S., 1993. The function of heat-shock proteins in stress tolerance: degradation and reactivation of damaged proteins. Annual Review of Genetics, 27 (1), 437-496.

Péres, A., Cahu, C.L., and Zambonino-Infante, J.L., 1997. Dietary spermine supplementation induces intestinal maturation in sea bass ( Dicentrarchus labrax ) larvae. Fish Physiology and Biochemistry, 16 (1), 479-485.

Picchietti, S., Fausto, A.M., Randelli, E., Carnevali, O., Taddei, A.R., Buonocore, F., Scapigliati, G., and Abelli, L., 2009. Early treatment with Lactobacillus delbrueckii strain induces an increase in intestinal T-cells and granulocytes and modulates immunerelated genes of larval Dicentrarchus labrax (L.). Fish \& shellfish immunology, 26 (3), 368-76.

Priest, F.G., Goodfellow, M., Shute, L.A., and Berkeley, R.C.W., 1987. Bacillus amyloliquefaciens sp. nov., nom. rev. International Journal of Systematic Bacteriology, 37 (1), 69-71.

Ray, A.K., Ghosh, K., and Ringø, E., 2012. Enzyme-producing bacteria isolated from fish gut: a review. Aquaculture Nutrition, 18 (5), 465-492.

Ridha, M.T. and Azad, I.S., 2012. Preliminary evaluation of growth performance and immune response of Nile tilapia Oreochromis niloticus supplemented with two putative probiotic bacteria. Aquaculture Research, 43 (6), 843-852.

Ringø, E. and Vadstein, O., 1998. Colonization of Vibrio pelagius and Aeromonas caviae in early developing turbot (Scophthalmus maximus L.) larvae. Journal of applied microbiology, 84 (2), 227-33.

Spinosa, M.R., Braccini, T., Ricca, E., De Felice, M., Morelli, L., Pozzi, G., and Oggioni, M.R., 2000. On the fate of ingested Bacillus spores. Research in microbiology, 151 (5), $361-8$.

Sun, Y.-Z., Yang, H.-L., Huang, K.-P., Ye, J.-D., and Zhang, C.-X., 2013. Application of autochthonous Bacillus bioencapsulated in copepod to grouper Epinephelus coioides larvae. Aquaculture, 392-395, 44-50.

Suzer, C., Coban, D., Kamaci, H., Saka, S., Firat, K., Otgucuoglu, O., and Kucuksari, H., 2008. Lactobacillus spp. bacteria as probiotics in gilthead sea bream (Sparus aurata, L.) larvae: Effects on growth performance and digestive enzyme activities. Aquaculture, $280(1-4), 140-145$.

Tao, Y., Drabik, K. a, Waypa, T.S., Musch, M.W., Alverdy, J.C., Schneewind, O., Chang, E.B., and Petrof, E.O., 2006. Soluble factors from Lactobacillus GG activate MAPKs and induce cytoprotective heat shock proteins in intestinal epithelial cells. American journal of physiology. Cell physiology, 290 (4), C1018-30. 
Touraki, M., Karamanlidou, G., Karavida, P., and Chrysi, K., 2012. Evaluation of the probiotics Bacillus subtilis and Lactobacillus plantarum bioencapsulated in Artemia nauplii against vibriosis in European sea bass larvae (Dicentrarchus labrax, L.). World journal of microbiology \& biotechnology, 28 (6), 2425-33.

Vaseeharan, B. and Ramasamy, P., 2003. Control of pathogenic Vibrio spp. by Bacillus subtilis BT23, a possible probiotic treatment for black tiger shrimp Penaeus monodon. Letters in applied microbiology, 36 (2), 83-7.

Vine, N.G., Leukes, W.D., and Kaiser, H., 2004. In vitro growth characteristics of five candidate aquaculture probiotics and two fish pathogens grown in fish intestinal mucus. FEMS microbiology letters, 231 (1), 145-52.

Wang, Y. and Gu, Q., 2010. Effect of probiotics on white shrimp ( Penaeus vannamei ) growth performance and immune response. Marine Biology Research, 6 (3), 327-332.

Wang, Y.-B., 2007. Effect of probiotics on growth performance and digestive enzyme activity of the shrimp Penaeus vannamei. Aquaculture, 269 (1-4), 259-264.

Wang, Y.-B., Li, J.-R., and Lin, J., 2008. Probiotics in aquaculture: Challenges and outlook. Aquaculture, 281 (1-4), 1-4.

Wang, Y.-B. and Zirong, X., 2006. Effect of probiotics for common carp (Cyprinus carpio) based on growth performance and digestive enzyme activities. Animal Feed Science and Technology, 127 (3-4), 283-292.

Welker, N.E. and Campbell, L.L., 1967. Unrelatedness of Bacillus amyloliquefaciens and Bacillus subtilis. Journal of bacteriology, 94 (4), 1124-30.

Williams, P., Winzer, K., Chan, W.C., and Cámara, M., 2007. Look who's talking: communication and quorum sensing in the bacterial world. Philosophical transactions of the Royal Society of London. Series B, Biological sciences, 362 (1483), 1119-34.

Ye, J.-D., Wang, K., Li, F.-D., and Sun, Y.-Z., 2011. Single or combined effects of fructoand mannan oligosaccharide supplements and Bacillus clausii on the growth, feed utilization, body composition, digestive enzyme activity, innate immune response and lipid metabolism of the Japanese flounder Paralichth. Aquaculture Nutrition, 17 (4), 902-911.

Yúfera, M. and Darias, M.J., 2007. The onset of exogenous feeding in marine fish larvae. Aquaculture, 268 (1-4), 53-63.

Zhou, X., Wang, Y., Yao, J., and Li, W., 2010. Inhibition ability of probiotic, Lactococcus lactis, against A. hydrophila and study of its immunostimulatory effect in tilapia (Oreochromis niloticus). International Journal of Engineering, Science and Technology, $2(7), 73-80$.

Ziaei-Nejad, S., Rezaei, M.H., Takami, G.A., Lovett, D.L., Mirvaghefi, A.-R., and Shakouri, M., 2006. The effect of Bacillus spp. bacteria used as probiotics on digestive enzyme 
activity, survival and growth in the Indian white shrimp Fenneropenaeus indicus. Aquaculture, 252 (2-4), 516-524. 


\section{Figure headlines}

Figure 1: Phylogenetic trees constructed using the neighbor-joining method for each of the isolated strains. The $\mathrm{N}$ join scale bar provides a horizontal distance scale.

Figure 2. Survival from hatching for snook, pompano and red drum at the end of the trial. Mean \pm standard error ( $\mathrm{n}=3$ for snook, $\mathrm{n}=4$ for pompano and red rum). Letters indicate significant differences.

Figure 3: Body depth and standard length of pompano and snook larvae at the end of the trial. Mean \pm standard error ( $\mathrm{n}=4$ for pompano, $\mathrm{n}=4$ for snook at 1 and 5 DPH then $\mathrm{n}=3,10$ larvae per tank and time point). Letters indicate significant differences between times and treatments.

Figure 4: Specific activities (U.mg ${ }^{-1}$ of protein) of trypsin, amylase, alkaline phosphatase (AP) and leucine-alanine peptidase (leu-ala) of snook and pompano larvae during the trial. Mean \pm standard error ( $\mathrm{n}=3$ and 4 respectively for snook and pompano, 50 larvae per tank). Letters indicate significant differences between treatments for snook (uppercase letters), pompano (italic uppercase letters) and between treatment and species (lower case letters). 
A)

N Join: $1.777 \%$

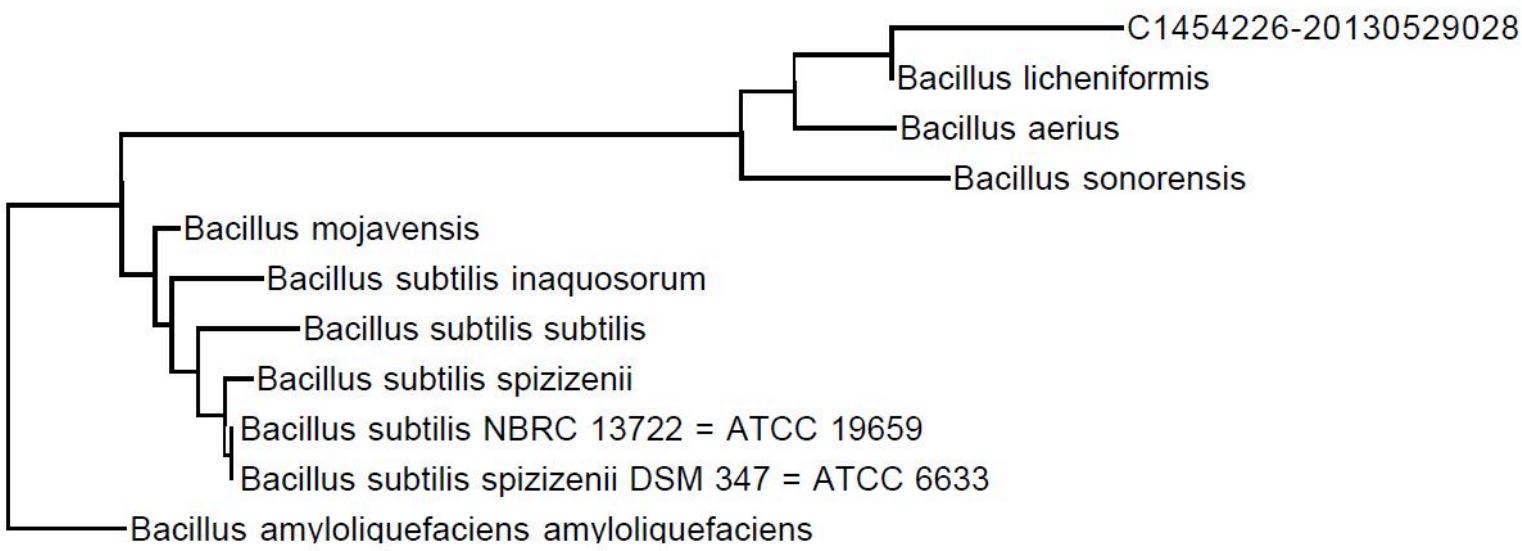

B)

N Join: $3.752 \%$

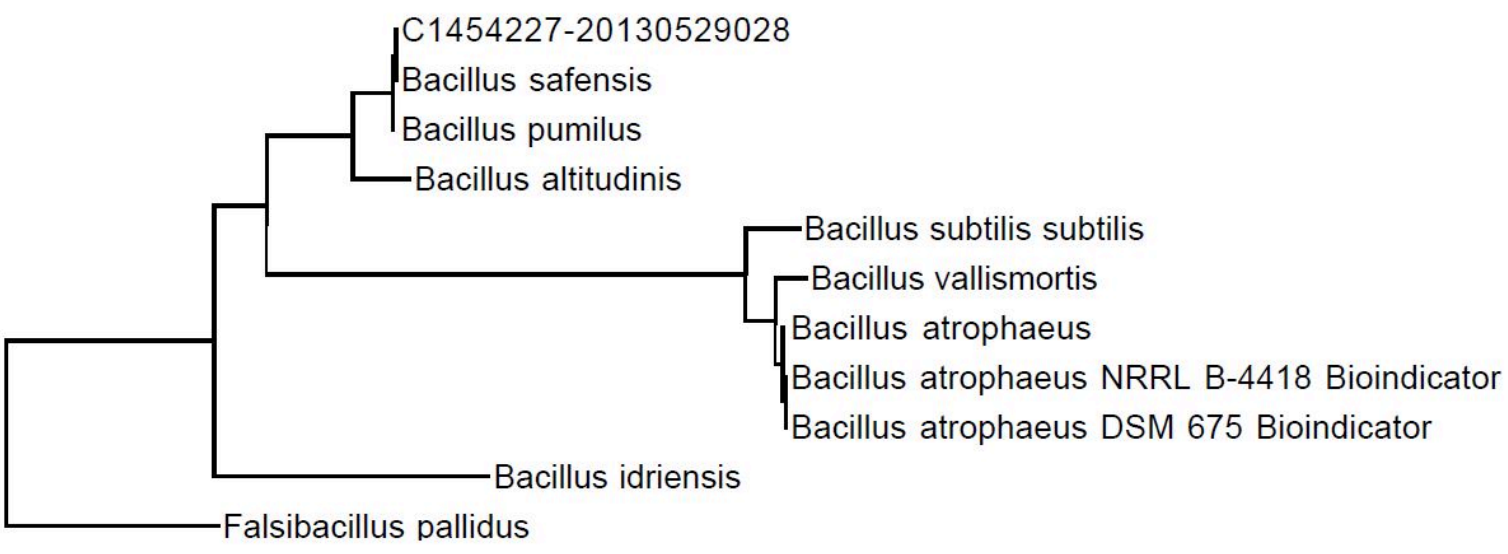

C)

$\mathrm{N}$ Join: $0.269 \%$

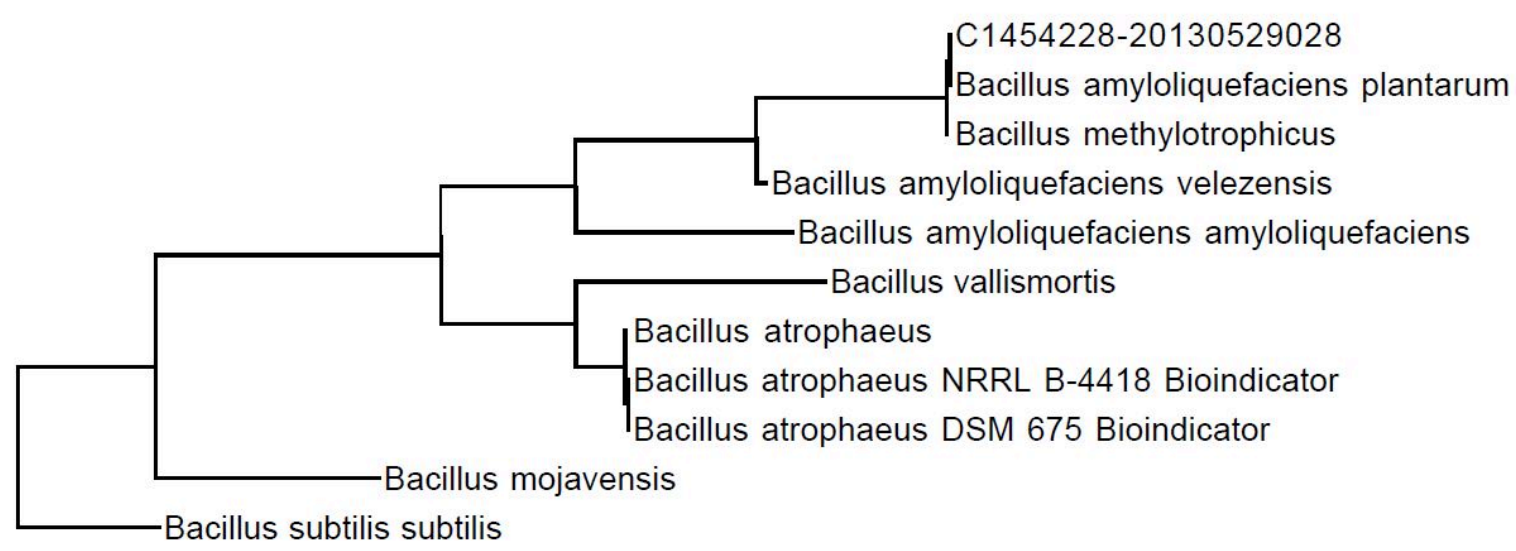

Figure 1 


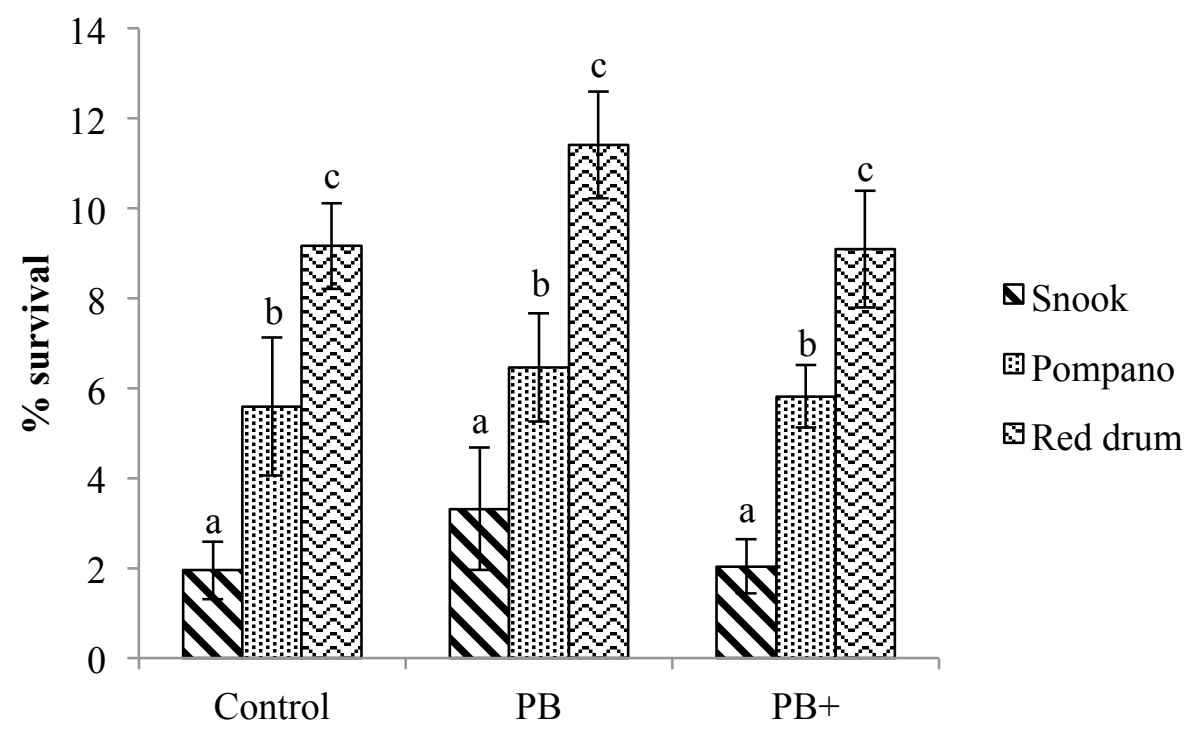

Figure 2. 


\section{A. Pompano}

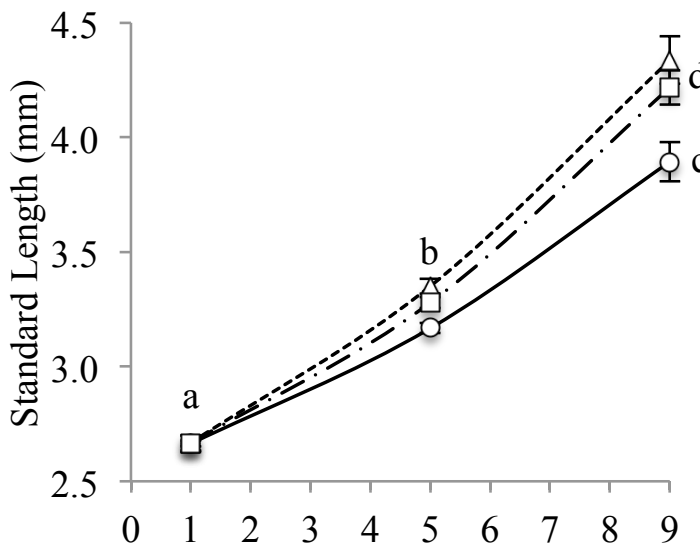

C. Snook

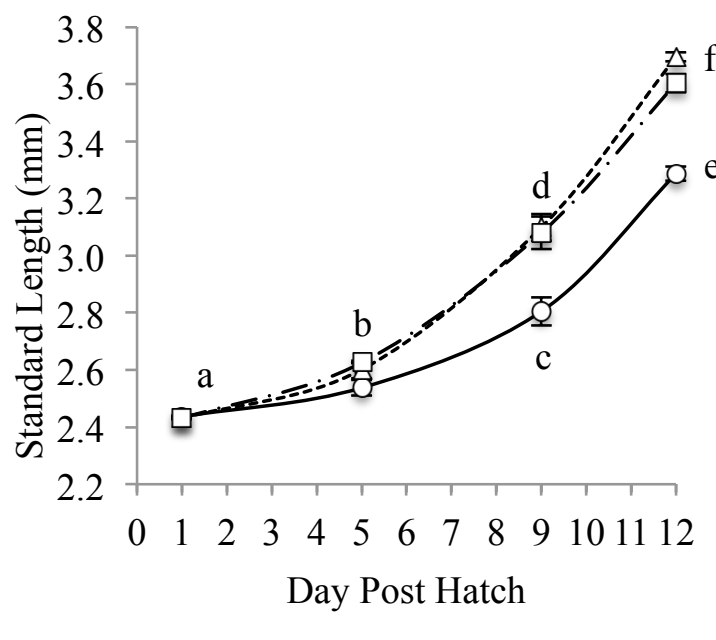

$\longrightarrow$ Control $\quad----\cdot-P B \quad-\square-P B+$

\section{B. Pompano}

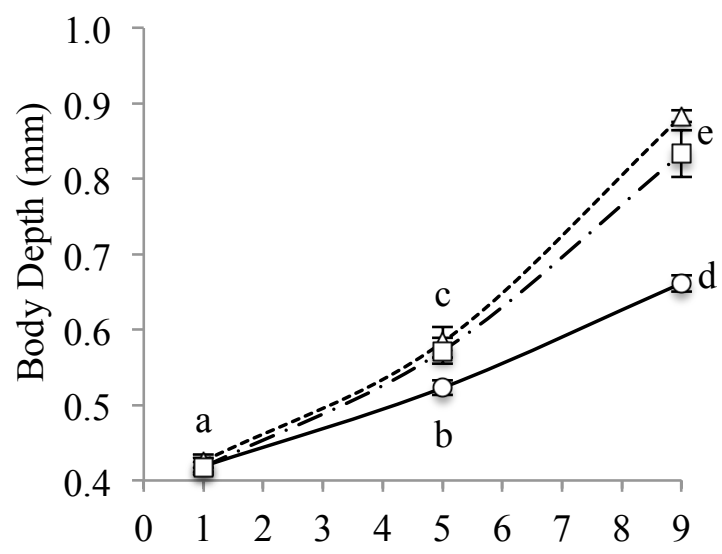

D. Snook

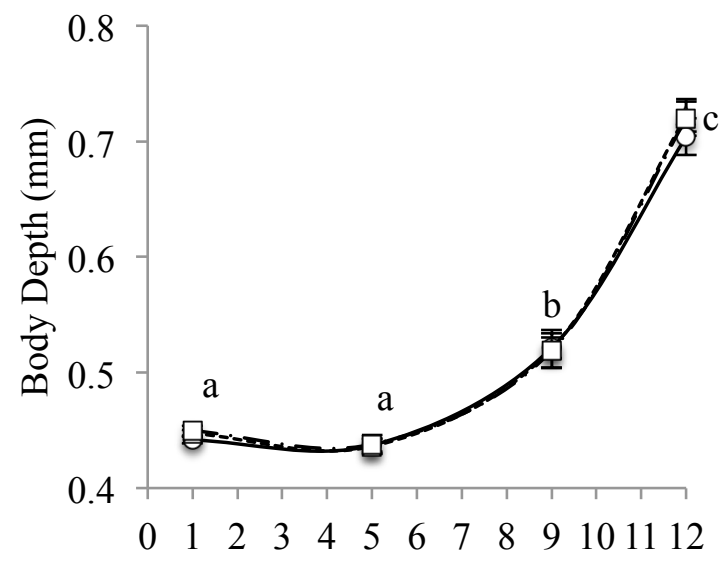

Figure 3. 


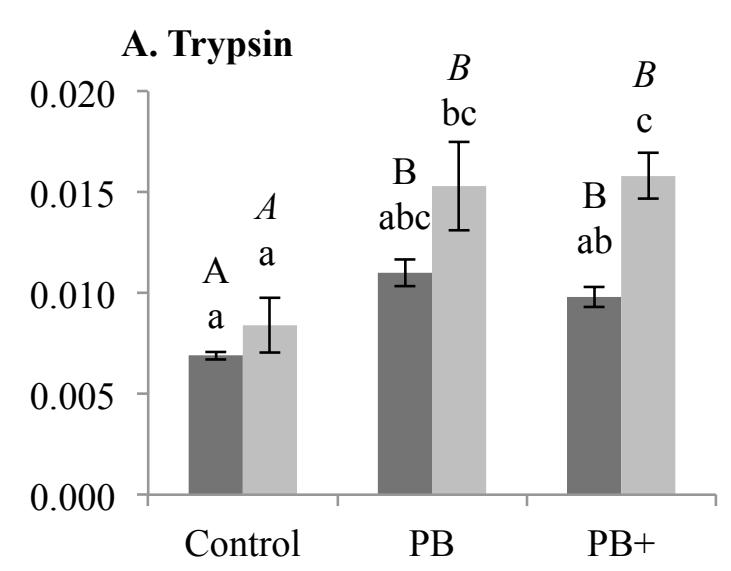

C. AP

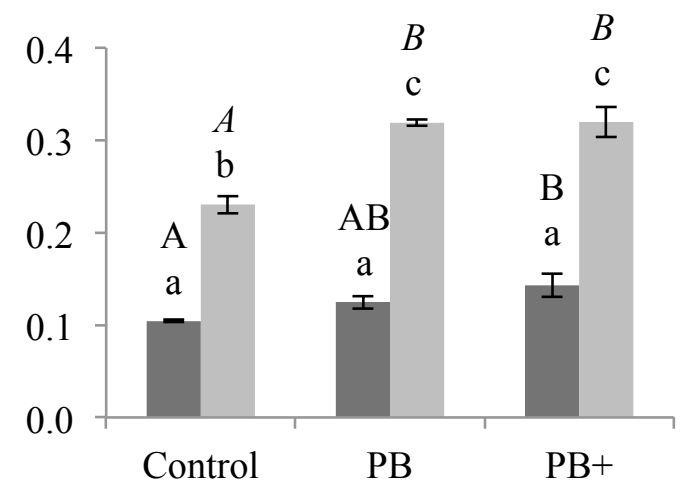

- Snook $\square$ Pompano

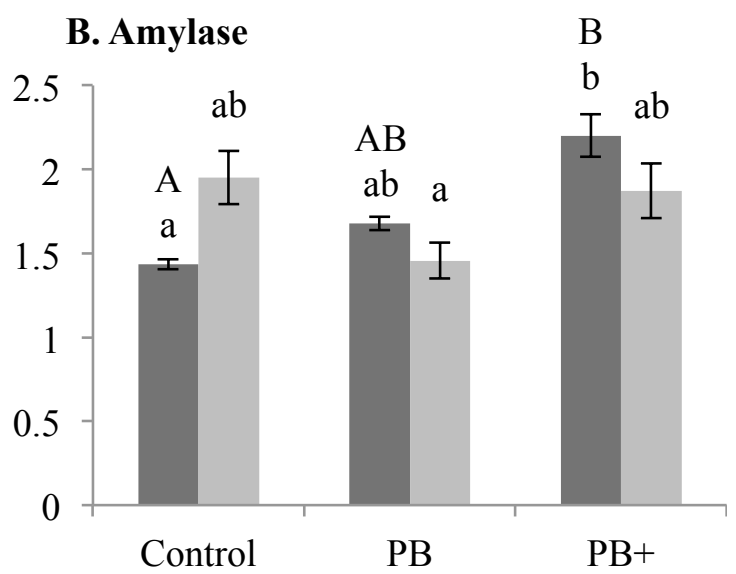

D. Leu-ala

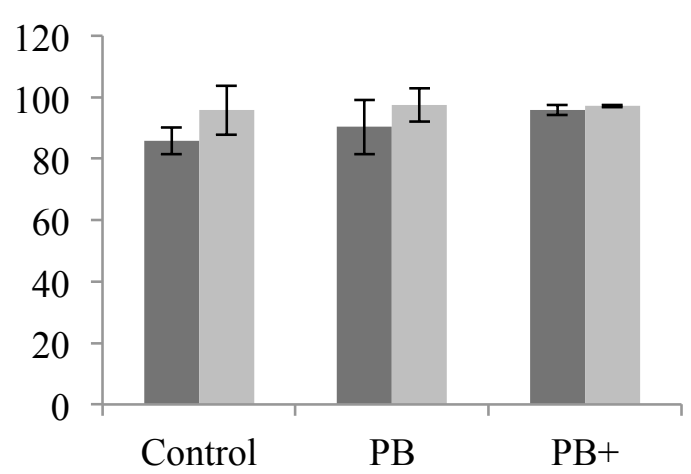

Figure 4. 
Table 1. Effects of a probiotic supplementation $(\mathrm{PB}$ and $\mathrm{PB}+)$ on standard length $(\mathrm{mm})$ and specific activities (U.mg ${ }^{-1}$ of protein) of trypsin, amylase, alkaline phosphatase (AP) and leucine-alanine peptidase (leu-ala) of red drum larvae. Mean \pm standard error ( $n=4$ tanks, 50 larvae per tank). No statistical differences were observed.

\begin{tabular}{|c|c|c|c|}
\hline & Control & PB & $\mathrm{PB}+$ \\
\hline \multicolumn{4}{|l|}{ Growth } \\
\hline $1 \mathrm{DPH}$ & $2.82 \pm 0.01$ & $2.81 \pm 0.02$ & $2.79 \pm 0.01$ \\
\hline $7 \mathrm{DPH}$ & $3.51 \pm 0.02$ & $3.55 \pm 0.01$ & $3.58 \pm 0.01$ \\
\hline $14 \mathrm{DPH}$ & $4.67 \pm 0.01$ & $4.48 \pm 0.03$ & $4.58 \pm 0.02$ \\
\hline $21 \mathrm{DPH}$ & $5.54 \pm 0.03$ & $5.45 \pm 0.08$ & $5.32 \pm 0.08$ \\
\hline \multicolumn{4}{|l|}{$\begin{array}{l}\text { Specific activity } \\
\text { at } 21 \mathrm{DPH}\end{array}$} \\
\hline Trypsin & $0.02 \pm 0.00$ & $0.02 \pm 0.00$ & $0.02 \pm 0.00$ \\
\hline Amylase & $0.56 \pm 0.04$ & $0.42 \pm 0.07$ & $0.51 \pm 0.03$ \\
\hline $\mathrm{AP}$ & $0.09 \pm 0.01$ & $0.08 \pm 0.01$ & $0.10 \pm 0.00$ \\
\hline Leu-ala & $145.8 \pm 4.2$ & $118.9 \pm 3.2$ & $143.1 \pm 5.8$ \\
\hline
\end{tabular}


Table 2. Number of colony-forming units $\left(\times 10^{3} \pm\right.$ standard error of the mean) per pompano larvae ( $\mathrm{n}=4$ tank, 10 larvae per tank) fed without probiotic supplementation (Control), with probiotic supplementation in the live food $(\mathrm{PB})$ or with probiotic supplementation in the live food and tank water $(\mathrm{PB}+)$. Superscript letters indicate significant differences within the same column (Tukey test, $\mathrm{p}<0.05$ ).

\begin{tabular}{ccc}
\hline & Marine Agar & TCBS \\
\hline Control & $1.0 \pm 0.6^{\mathrm{a}}$ & $0.01 \pm 0.00^{\mathrm{a}}$ \\
PB & $38 \pm 8^{\mathrm{b}}$ & $0.15 \pm 0.01^{\mathrm{a}}$ \\
PB + & $18 \pm 22^{\mathrm{b}}$ & $0.02 \pm 0.01^{\mathrm{a}}$ \\
\hline
\end{tabular}

